\title{
THE ANGLE OF THE LIGHT ON THE BLOODSTAINED KITCHEN FLOOR
}

\author{
4 p.m. Friday 22 November 1963.
}

\section{BY MATT MIKALATOS}

$\mathrm{D}$ octor Wallace told me that the 22 November 1963 would be my assigned topic for the final exam. I've studied and crammed and memorized and watched holos and paid for memory boosts. But when I put on the Chronovisor, it doesn't show me Dallas, it shows me Tony Acerbi's apartment.

So I do the research while my exam timer counts down. Dr Wallace has given me a two-week window of chronal study, culminating here on the 22nd.

I learn that Tony Acerbi lives in a fetid hole of an apartment. He has way more cockroaches than friends. He wears slacks and a filthy undershirt most of the day, and lives on boosted merchandise and odd jobs. His home is in a Chicago neighbourhood where you call the cops and make bets on whether they'll show. 60-40 they don't.

Tony's neighbour is this old black man named Ollie Lewis. He's tied with Tony for most hated man in the complex. Everyone's pretty sure he poisoned the barking dog in $3 \mathrm{~A}$, and he definitely empties his ashtray into Mrs Fortuna's flower box.

At 3.42 p.m. on 22 November, two teenagers break into Ollie's place.

Tony is sitting in his easy chair smoking a cigarette and he hears the muffled sounds of the old man next door getting worked over. He jumps up and, without putting on a jacket, or a shirt for that matter, he runs through the November cold and busts into Ollie's apartment.

Ollie is on the floor, curled in a ball. One kid has a Louisville Slugger, the other has steel-toed boots. Tony takes a couple of swings at them, but they're not interested. They keep taking jabs at Ollie. So Tony lays

$\rightarrow$ NATURE.COM

Follow Futures:

* @NatureFutures

f gonnature.com/mtoodm down over Ollie, covering the man's head with his own body.

The kids barely pause, but now most of their blows are hitting Tony. There is blood everywhere. Tony, at a certain point, just turns his head to one side and stares at the floor, and the fading sunlight through the dirty window illuminates every mote of dust, like a thousand bursting stars drifting through his neighbour's kitchen.

happens by to water her flowers and when she sees the men collapsed in Ollie's kitchen, she screams and runs for her phone and calls the police, the fire department, the ambulances, anyone, anyone, please God, just send anyone.

I probably couldn't even write a thesis about Tony Acerbi or Ollie Lewis. There won't be a holo. They're nobodies and the resources for chronal viewing are tight. Dr Wallace picked an obscure moment because he likes his students to observe details, to see things fresh, and it's hard to do that with the big historical events. So he chose this little corner of nowhere as a test, not because he thinks it's important.

What happened to these two doesn't matter. Not to my grade, not to my future, not to history or the fate of the country.

None of it matters. The identity of the teenagers, the amount of blood lost, the pattern in the wallpaper, the

I can't go much beyond this moment in the kitchen, and I can't see places other than these two apartments. I can't figure out why the teens are doing this, or why Tony is protecting Ollie. I don't see a reason for him to lay himself down like a shroud over his neighbour.

I click my teeth in annoyance that Dr Wallace has done this to me, given me this particular moment on this day of all days. I have to wonder if Tony knows how inconsequential this moment is. A couple of hours from now, JFK takes a bullet to the head. Aldous Huxley and C. S. Lewis both breathe their last. Hell, today The Beatles release their second album. Doctor Who has its series premiere less than 24 hours from this moment.

Two men in a dilapidated apartment complex being beaten senseless by teenagers, it means less than nothing. You don't get grants, you don't get book deals, you don't get tenure by studying unimportant events.

The two men breathe shallowly and twitch on the yellowed linoleum. Their breath stirs ripples in the growing puddle of blood. The teenagers leave them, leaving the door open.

Two and a half minutes later, Mrs Fortuna 